\title{
Impending Pollution of Betare Oya Opencast Mining Environment (Eastern Cameroon)
}

Tehna Natanael ${ }^{1,2,3}$, Nguene Feudoung Daniel ${ }^{2}$, Etame Jacques ${ }^{1}$, Medza Ekodo Jean Marc ${ }^{4}$, Noa Tang Sylvie ${ }^{1}$, Suh Emmanuel Cheo ${ }^{5}$ and Bilong Paul ${ }^{2}$

1. Department of Earth Sciences, Faculty of Sciences, University of Douala, Douala 24157, Cameroon

2. Department of Earth Sciences, Faculty of Sciences, University of Yaounde I, Yaounde 812, Cameroon

3. Department of Mines, Ministry of Mines, Industry and Technological Development, Yaounde 70, Cameroon

4. Seismology Laboratory of Ekona, Geophysics and Volcanic Research Department, Institute of Mining and Geological Research,

Buea 370, Cameroon

5. Department of Geology and Environmental Science, Economic Geology Unit, University of Buea, Buea 63, Cameroon

\begin{abstract}
Mining resources are offered by the natural milieu and liable to exploitation. Raw materials extracted are essential for jewellery and economy. But in most cases, the environmental impact assessment is disappointing. In this study conducted at Betare Oya, mining residues are directly disposed in the immediate environment without passing through the tailing ponds for treatment, despite environmental laws and standards. Soluble components of matter are slowly dissolved, drained by meteoric water and flowed into tail bay vicinity. Soil and mining residues were sampled in Mari, Mbigala, Mboufa and Bedobo, respectively, four sub-watershed of Lom, the main river of the region. Concentration of nine MTE (metallic trace elements): $\mathrm{As}, \mathrm{Cd}, \mathrm{Cr}, \mathrm{Cu}, \mathrm{Co}, \mathrm{Ni}, \mathrm{Pb}$, $\mathrm{Zn}$ and $\mathrm{Hg}$ were determined by ICP-MS (inductively coupled plasma-mass spectrometry). Highest concentrations of trace and toxic metals in soil and mining residues are: $\mathrm{Cr}\left(210 \mathrm{mg} \cdot \mathrm{kg}^{-1}\right)>\mathrm{Zn}\left(136 \mathrm{mg} \cdot \mathrm{kg}^{-1}\right)>\mathrm{Ni}\left(64 \mathrm{mg} \cdot \mathrm{kg}^{-1}\right)>\mathrm{As}\left(34 \mathrm{mg} \cdot \mathrm{kg}^{-1}\right)>\mathrm{Cu}\left(30 \mathrm{mg} \cdot \mathrm{kg}^{-1}\right)>$ $\mathrm{Pb}\left(25 \mathrm{mg} \cdot \mathrm{kg}^{-1}\right)>\mathrm{Co}\left(17 \mathrm{mg} \cdot \mathrm{kg}^{-1}\right)>\mathrm{Cd}\left(0.5 \mathrm{mg} \cdot \mathrm{kg}^{-1}\right)>\mathrm{Hg}\left(0.1 \mathrm{mg} \cdot \mathrm{kg}^{-1}\right)$, respectively. These results let assume that it is a risk of environmental pollution and poisoning relative to these elements around Betare Oya opencast mining area, with impact on human health.
\end{abstract}

Key words: Mining, mounds mining residues, pollution, metallic trace elements, toxicology.

\section{Introduction}

Previous studies carried out over the last century have shown that Betare Oya is a higher gold zone grade. The alluvial gold found in these soils has led to a significant mining activity dating back to the beginning of colonization. It has increased from 1934 with the launching of the first major gold projects in this region. Indeed, mining has been one of the fundamental pillars of the Cameroonian economy for long ago, and the metallurgical sector has experienced substantial growth since the adoption in 2001 of the new mining code. Cameroon's gold production had

Corresponding author: Nguene Feudoung Daniel, Ph.D., researcher, research fields: hydrology, cleaning up and environmental sciences. E-mail: nguenefd@yahoo.fr. reached $717 \mathrm{~kg}$ in 1942 [1]. Mines operated by small-scale miners of Betare Oya have deeply contributed to the local production.

Betare Oya is located in the southern Cameroon plateau with heights ranging from $700 \mathrm{~m}$ to $900 \mathrm{~m}$. It is characterized by a monotonous landscape of undulating hill-shaped domes [2-4]. The climate is a Sub-Equatorial Guinea, with bimodal rainfall (two rainy seasons and two dry seasons, with an average annual rainfall of over 1,500 $\mathrm{mm}$ ).

The opencast mining study area is located in the east of Cameroon. It covers $210 \mathrm{~km}^{2}$ and stretches between north latitudes $5^{\circ} 32^{\prime} 32^{\prime \prime}$ to $5^{\circ} 44^{\prime} 25^{\prime \prime}$, and east longitudes $14^{\circ} 00^{\prime} 18^{\prime \prime}$ to $14^{\circ} 12^{\prime} 24^{\prime \prime}$ (Fig. 1).

This area has been undergoing intense surface gold 


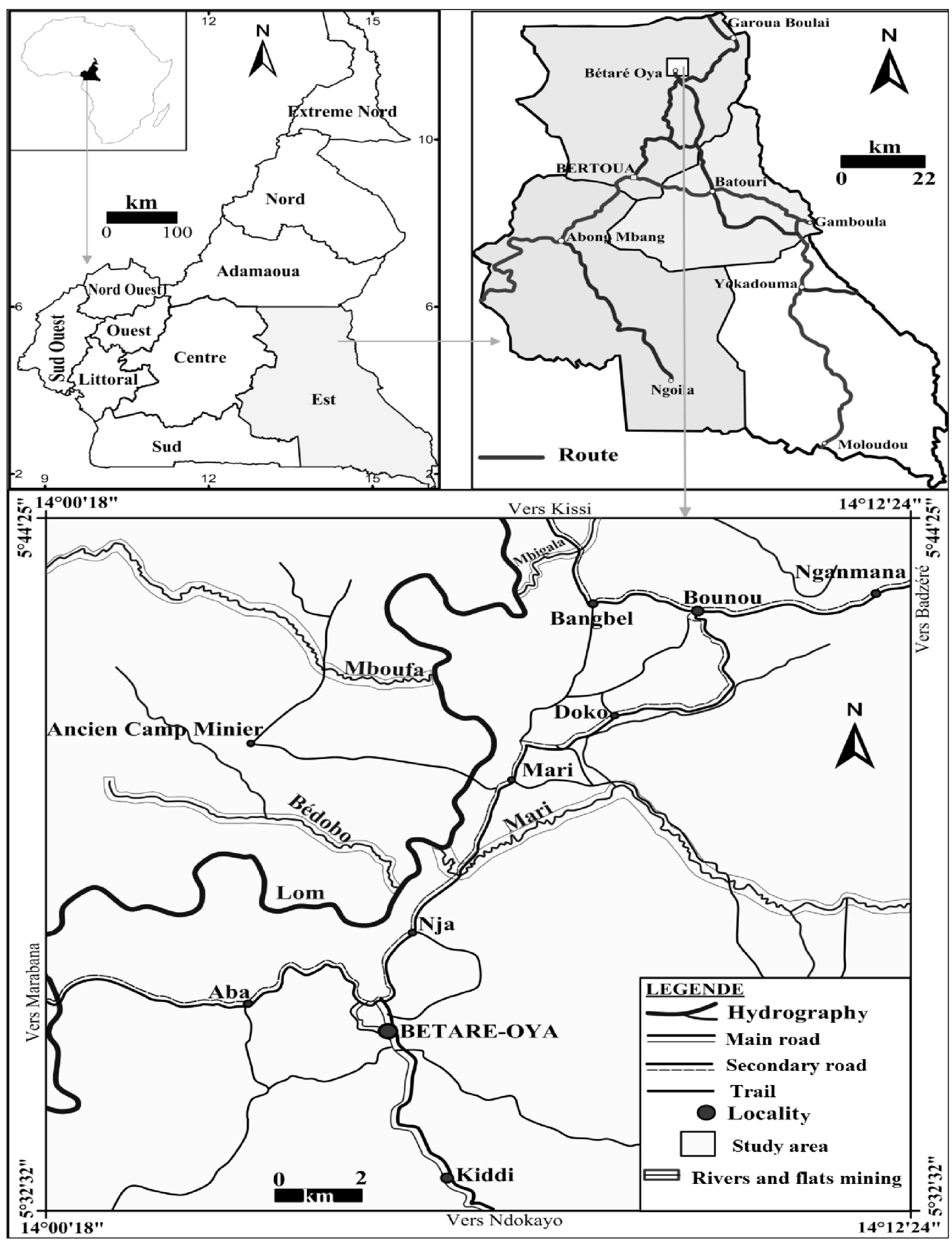

Fig. 1 Map of current mining sites in the study area. 
mining since 2006. Gold mineralization takes place under sterile layers $1 \mathrm{~m}$ to $8 \mathrm{~m}$ thick. Mineralized layers consist of a mixture of gravel, sand and clay. They are often very rich in gold at the contact of gravel/bedrock [5]. The mineralization is also divided into diffuse and pervasive quartz veinlets, apparently consistent with the schistosity. Conglomerate beds constitute the lithological type which owns the majority of gold ore in current mining. At the start of operations, gold ore reserves were roughly estimated at $6 \mathrm{t}$ with an average grade of $1 \mathrm{~g} \cdot \mathrm{m}^{-3}$ [6].

It is known that about 70 companies are operating in gold ore processing by sifting without any settling pond, by using river water, mercury, chloride acid, and sulphuric acid as chemical reagents.

Nowadays, Betare Oya gold production is monthly evaluated to $400 \mathrm{~kg}$ [7]. Gold mining activities in the eastern region of Cameroon are taking place in alluvial placer and weathered quartz veins, respectively. Modernization of mining equipment is undergoing significant changes with introduction of excavators, mechanized washing stations, centrifugal pumps and modern recovery methods and enrichment of valuable substances. Nevertheless, usual mining techniques involves landscape deforestation, pits digging, spoil material crowding and destruction of watering places. The protection of the environment is not appearing as a major concern in mining processes. In fact, soils destroyed for mineralized layer recovery purposes are abandoned without being rehabilitated (Figs. 2 and 3). Mining residues are discharged in the immediate environment without any treatment, and may lead to the contamination of surface and groundwater, sediments, soils and plants [8-10].

\section{Materials and Methods}

Sampling was performed at Mari, Mbigala, Mboufa and Bedobo, which are the four major tributaries of Lom sub-basins. Sampling was based on the proximity to potential pollution sources of mine (mining residues) due to processing, the presence of water flows and other activities (agricultural, livestock...). Samples of mineralized layers and processing mining residues were collected in clean plastic bags from wellbore 200 $\mathrm{cm}$ from the surface. They were dried and crushed at the Laboratory of Soil Sciences, University of Yaounde I, then sent to Analytical Chemistry and Testing Services Laboratory in Canada for chemical analysis.

Samples were pre-treated according to the protocol developed, then digested for extraction and determination of MTE (metallic traces element) concentration by ICP-MS (inductively coupled plasma-mass spectrometry) (Figs. 4 and 5).

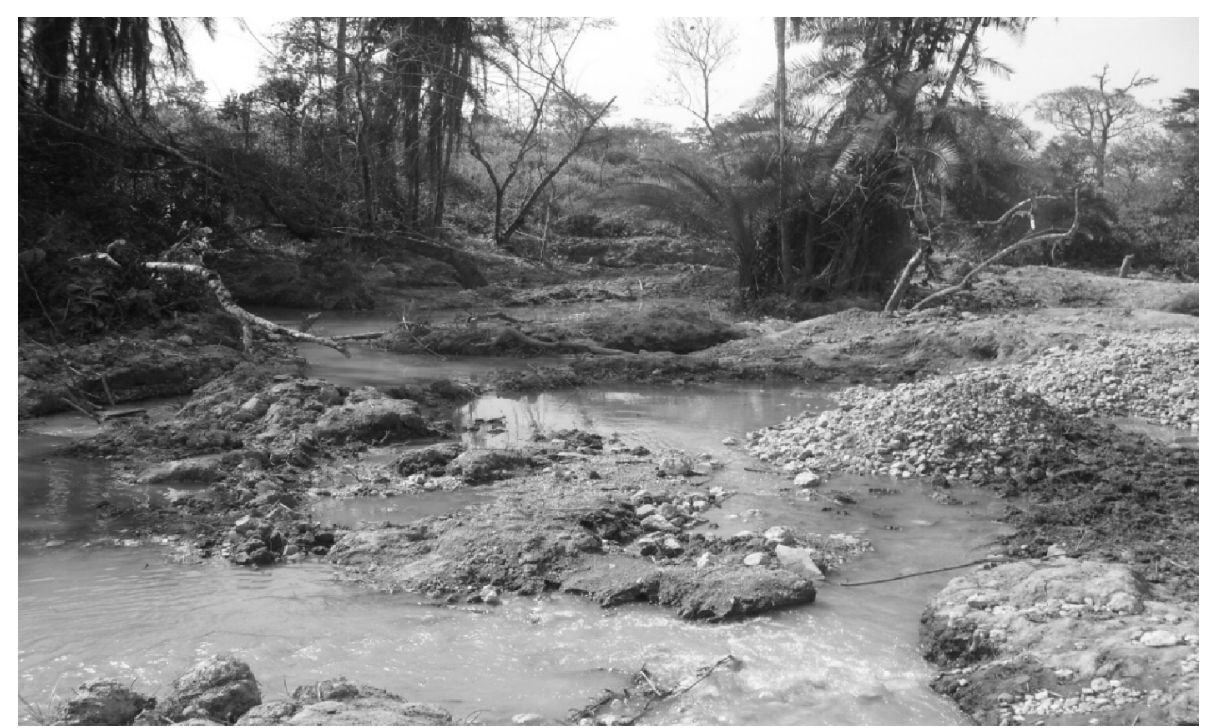

Fig. 2 Destruction of the gallery forest in the area of Betare Oya. 


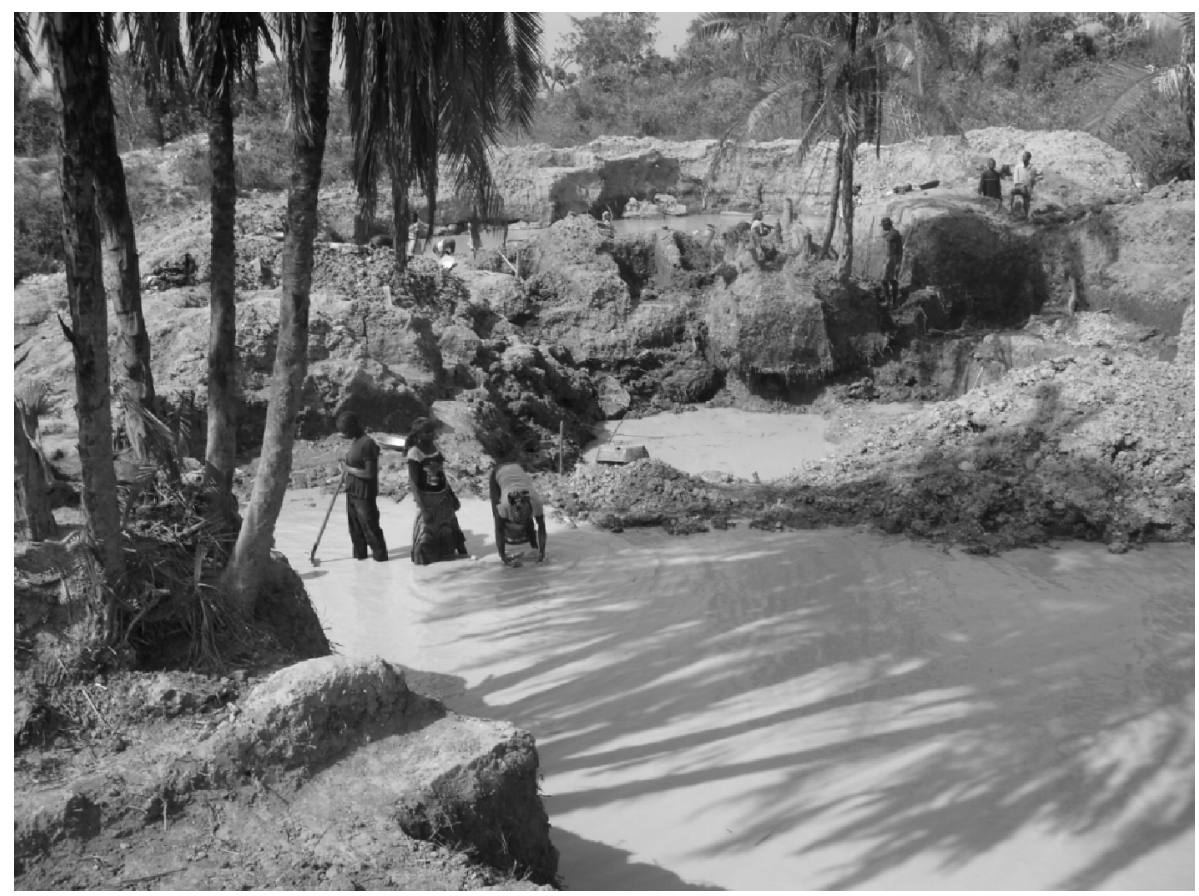

Fig. 3 Changing the landscape by mining activities in Betare Oya.

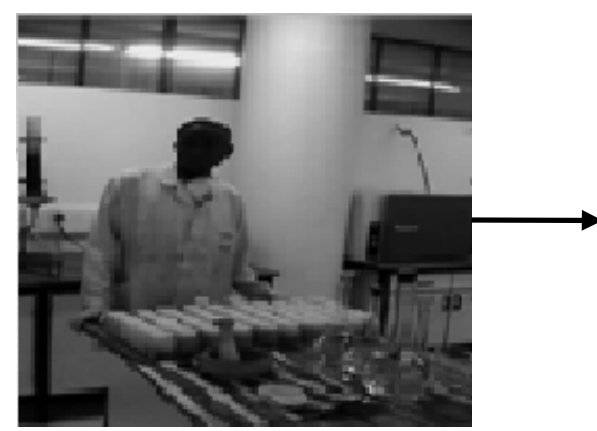

Samples crushing

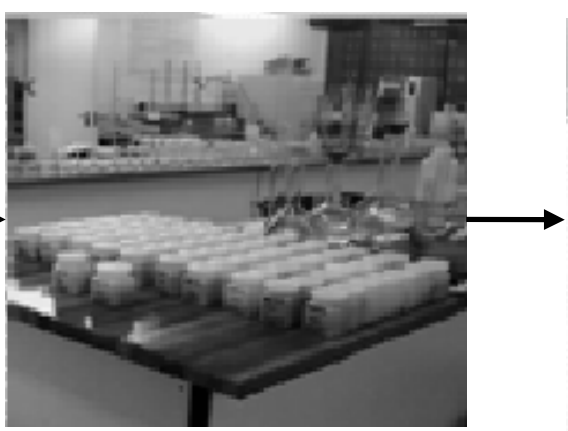

Sieving and conservation in PVC (poly vinyl chloride) jar

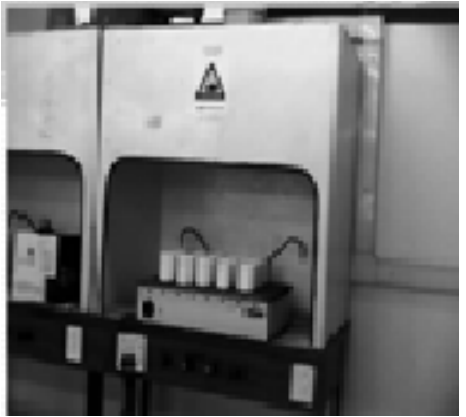

Plate heating digestion in Tefon cup

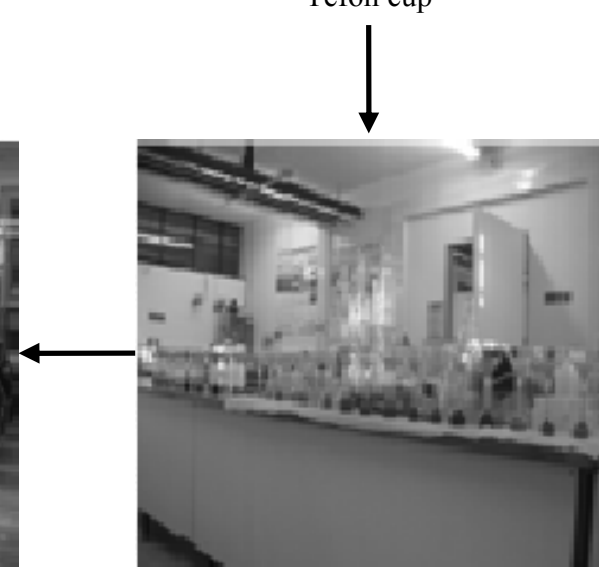

Filtration after digestion

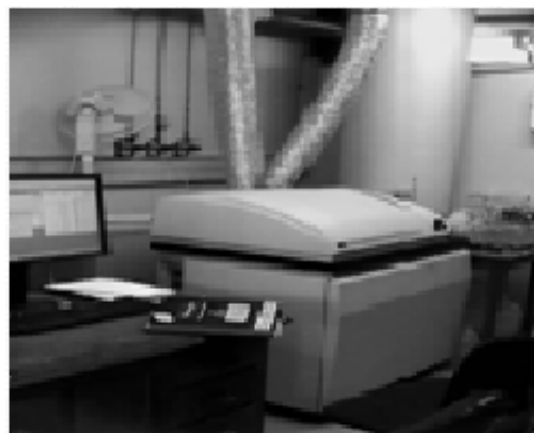

Analysis in ICP-MS

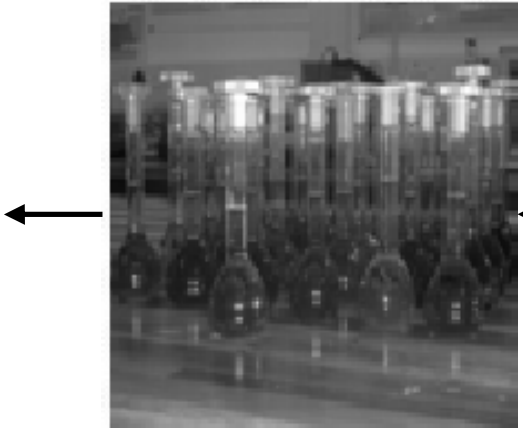

Filtrate conservation

Fig. 4 Sample protocol of digestion and analysis in ICP-MS. 


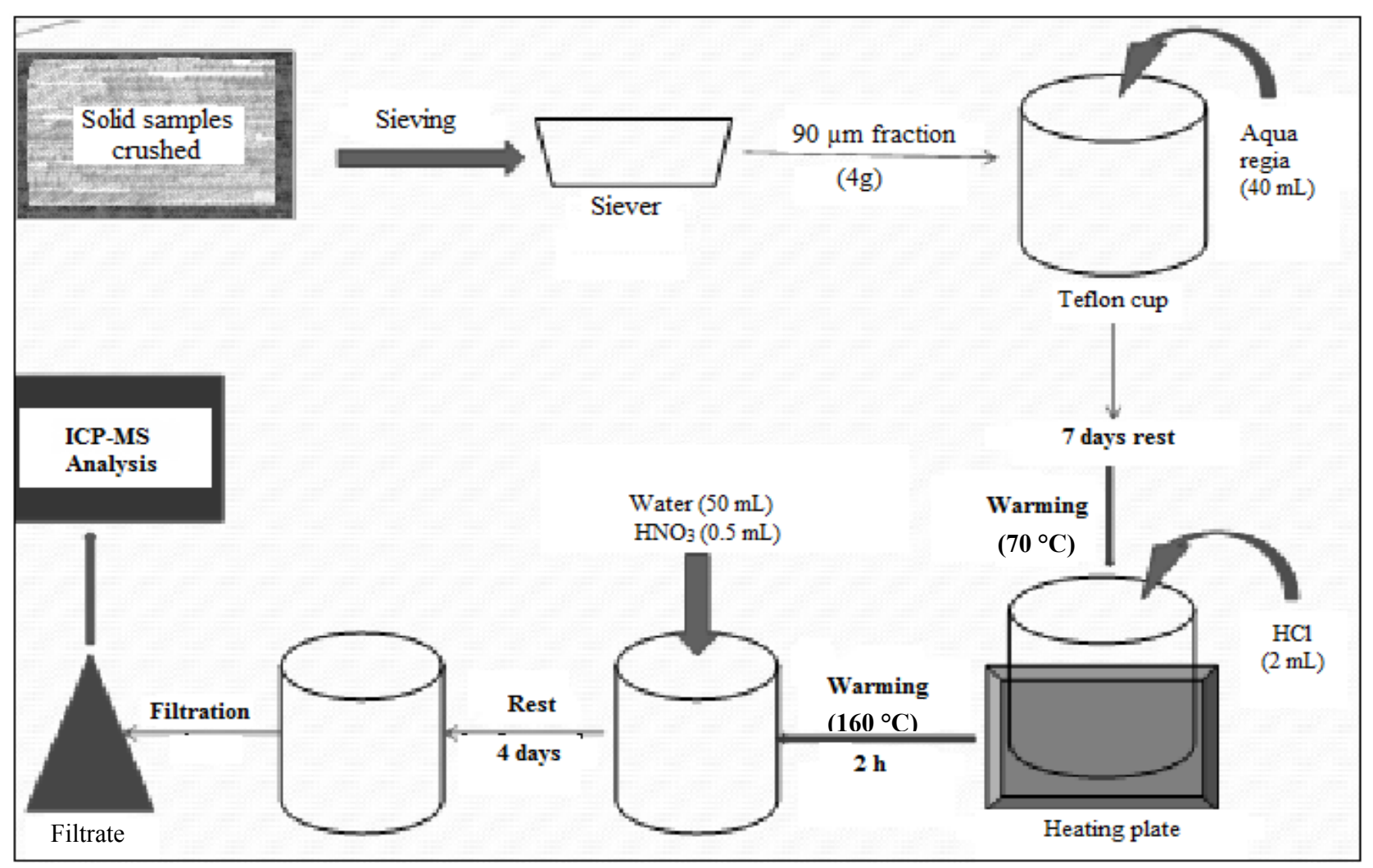

Fig. 5 Digestion method for extraction of MTE and ICP-MS analysis.

\section{Results}

\subsection{Concentration of MTE in Soils and Mining} Processing Residues

MTE concentrations are much diversified from an element to another, showing their particularity (Table 1). As concentrations fluctuate between 1.4-37.1 $\mathrm{mg} \cdot \mathrm{kg}^{-1}$. While concentrations of other metallic trace elements are respectively lined between 0.1-0.5 $\mathrm{mg} \cdot \mathrm{kg}^{-1}$ for $\mathrm{Cd}, 140.0-210.0 \mathrm{mg} \cdot \mathrm{kg}^{-1}$ for $\mathrm{Cr}$, 7.0-30.0 mg. $\mathrm{kg}^{-1}$ for $\mathrm{Cu}, 2.0-17.0 \mathrm{mg} \cdot \mathrm{kg}^{-1}$ for $\mathrm{Co}$, 7.0-64.0 mg. $\mathrm{kg}^{-1}$ for $\mathrm{Ni}, 5.0-25.0 \mathrm{mg} \cdot \mathrm{kg}^{-1}$ for $\mathrm{Pb}$, and 11.0-136.0 $\mathrm{mg} \cdot \mathrm{kg}^{-1}$ for $\mathrm{Zn}$. MTE concentrations in soils are contrasting with those in mining processing residues. The highest concentration sequence is as follow: $\mathrm{Cr}>\mathrm{Zn}>\mathrm{Ni}>\mathrm{As}>\mathrm{Cu}>\mathrm{Pb}>\mathrm{Co}>\mathrm{Cd}>\mathrm{Hg}$.

\subsection{Concentration of MTE in Soils Liable to Mining Activities}

$\mathrm{Cr}, \mathrm{Zn}, \mathrm{Ni}, \mathrm{As}, \mathrm{Cu}, \mathrm{Pb}, \mathrm{Co}, \mathrm{Cd}$ and $\mathrm{Hg}$ were found in soils liable to mining activities. Compared with average concentrations in the earth's crust [11] and the global standards, it appears that concentrations of some MTE (Cr, Cd, Pb, As and $\mathrm{Zn}$ ) are higher. They are lined between $150.0-210.0 \mathrm{mg} \cdot \mathrm{kg}^{-1}$ for $\mathrm{Cr}, 0.1-0.5$ $\mathrm{mg} \cdot \mathrm{kg}^{-1}$ for $\mathrm{Cd}, 5.0-25.0 \mathrm{mg} \cdot \mathrm{kg}^{-1}$ for $\mathrm{Pb}, 1.4-37.1$ $\mathrm{mg} \cdot \mathrm{kg}^{-1}$ for As and $11.0-85.0 \mathrm{mg} \cdot \mathrm{kg}^{-1}$ for $\mathrm{Zn}$, respectively (Fig. 6). The contents of $\mathrm{Cr}$ and $\mathrm{Zn}$ are the most important identified in these soils. Those of $\mathrm{Ni}\left(7.0-30.0 \mathrm{mg} \cdot \mathrm{kg}^{-1}\right), \mathrm{Cu}\left(7.0-30.0 \mathrm{mg} \cdot \mathrm{kg}^{-1}\right), \mathrm{Co}$ (2.0-9.0 $\left.\mathrm{mg} \cdot \mathrm{kg}^{-1}\right)$ and $\mathrm{Hg}\left(0.01-0.06 \mathrm{mg} \cdot \mathrm{kg}^{-1}\right)$ are lower than average concentration in the earth's crust. The highest concentration sequence is as follow: $\mathrm{Cr}>$ $\mathrm{Zn}>\mathrm{Ni}>\mathrm{Cu}>\mathrm{As}>\mathrm{Pb}>\mathrm{Co}>\mathrm{Hg}>\mathrm{Cd}$.

\subsection{Concentration of MTE in Mounds Mining Residues}

MTE raise up was found in mounds mining residues. All concentrations are in a normal row. But it appears that concentrations of some MTE $(\mathrm{Cr}, \mathrm{Cd}, \mathrm{Pb}, \mathrm{As}$ and $\mathrm{Zn}$ ) are higher than the average concentrations in the earth's crust. They are lined between 140.0-210.0 
Table 1 Betare Oya MTE concentrations in soils and mounds mining residues.

\begin{tabular}{|c|c|c|c|c|c|c|c|c|c|}
\hline & $\mathrm{Zn}$ & $\mathrm{Ni}$ & $\mathrm{Cu}$ & As & $\mathrm{Pb}$ & $\mathrm{Co}$ & $\mathrm{Cd}$ & $\mathrm{Hg}$ & $\mathrm{Cr}$ \\
\hline Earth crust concentration & 80 & 105 & 75 & 5 & 8 & 29 & 0.015 & 0.085 & 185 \\
\hline International norms & $300^{(7)}$ & $50^{(5)}$ & $100^{(4)}$ & $6^{(1)}$ & $100^{(6)}$ & $40^{(8)}$ & $1^{(2)}$ & $1^{(9)}$ & $100^{(3)}$ \\
\hline & \multicolumn{9}{|c|}{ MTE concentration in soils $\left(\mathrm{mg} \cdot \mathrm{kg}^{-1}\right)$} \\
\hline Mari & 11.0 & 7.0 & 7.0 & 1.4 & 5.0 & 2.0 & $<0.5$ & 0.057 & 180.0 \\
\hline Mbigala & 42.0 & 29.0 & 25.0 & 18.0 & 13.0 & 9.0 & $<0.5$ & 0.032 & 210.0 \\
\hline Mboufa & 85.0 & 24.0 & 17.0 & 2.6 & 10.0 & 9.0 & $<0.5$ & $<0.005$ & 200.0 \\
\hline \multirow[t]{2}{*}{ Bedobo } & 60.0 & 30.0 & 30.0 & 37.1 & 25.0 & 5.0 & $<0.5$ & 0.015 & 150.0 \\
\hline & \multicolumn{9}{|c|}{ MTE concentrations in mounds mining residues $\left(\mathrm{mg} \cdot \mathrm{kg}^{-1}\right)$} \\
\hline Mari & 54.0 & 23.0 & 16.0 & 4.1 & 14.0 & 8.0 & $<0.5$ & 0.011 & 210.0 \\
\hline Mbigala & 136.0 & 64.0 & 27.0 & 0.2 & 20.0 & 17.0 & $<0.5$ & 0.007 & 170.0 \\
\hline Mboufa & 52.0 & 25.0 & 22.0 & 10.6 & 23.0 & 5.0 & $<0.5$ & 0.019 & 140.0 \\
\hline Bedobo & 70.0 & 31.0 & 17.0 & 6.4 & 23.0 & 6.0 & $<0.5$ & 0.017 & 170.0 \\
\hline
\end{tabular}

${ }^{(1)}$ World average of soils uncontaminated in As [9]; ${ }^{(2)}$ reference value for the Cd of the British Agency for urban soils [12]; ${ }^{(3)} \mathrm{Cr}$ limit value [13]; ${ }^{(4)} \mathrm{Cu}$ acceptable level of concentration in the soils (Formazine Nephelometric Unit 4405$) ;{ }^{(5)} \mathrm{Ni}$ limit value [14]; ${ }^{(6)} \mathrm{Pb}$ critical value indicated by the WHO (World Health Organisation) $[15] ;{ }^{(7)} \mathrm{Zn}$ critical values indicated by the WHO [15]; ${ }^{(8)} \mathrm{Co} \mathrm{critical}$ values [16]; ${ }^{(9)} \mathrm{Hg}$ critical value [17].

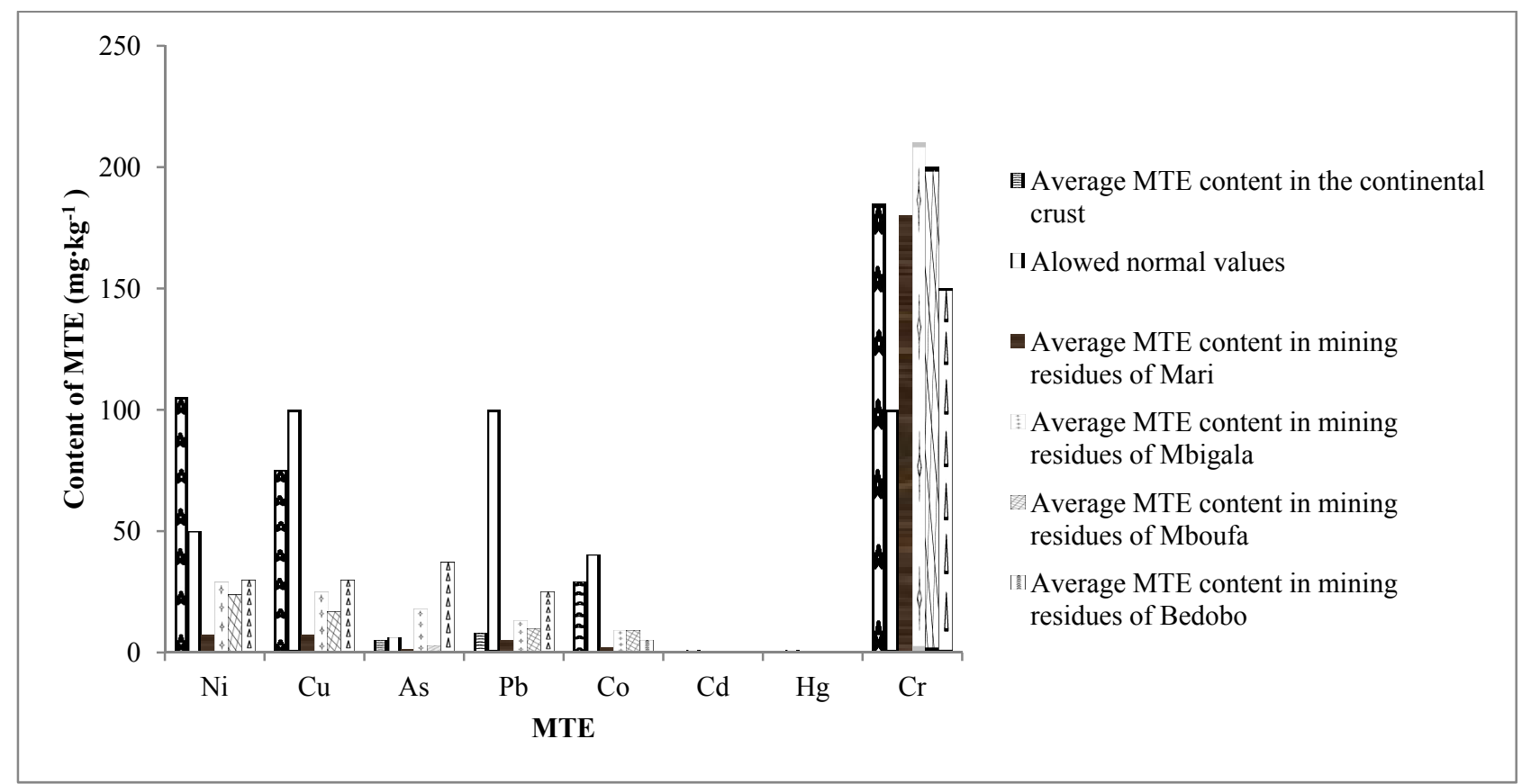

Fig. 6 Betare Oya MTE concentration in soils.

$\mathrm{mg} \cdot \mathrm{kg}^{-1}$ for $\mathrm{Cr}, 0.1-0.5 \mathrm{mg} \cdot \mathrm{kg}^{-1}$ for $\mathrm{Cd}, 14.0-23.0$ $\mathrm{mg} \cdot \mathrm{kg}^{-1}$ for $\mathrm{Pb}, \quad 0.2-10.6 \mathrm{mg} \cdot \mathrm{kg}^{-1}$ for As and 52.0-136.0 mg. $\mathrm{kg}^{-1}$ for $\mathrm{Zn}$, respectively (Fig. 7). As well as in soils liable to mining activities, the contents of $\mathrm{Cr}$ and $\mathrm{Zn}$ are the most important identified in mounds mining residues. Concentrations of $\mathrm{Ni}$ $\left(16.0-27.0 \mathrm{mg} \cdot \mathrm{kg}^{-1}\right), \quad \mathrm{Cu} \quad\left(0.2-10.6 \mathrm{mg} \cdot \mathrm{kg}^{-1}\right), \quad \mathrm{Co}$ $\left(5.0-17.0 \mathrm{mg} \cdot \mathrm{kg}^{-1}\right)$ and $\mathrm{Hg}\left(0.01-0.02 \mathrm{mg} \cdot \mathrm{kg}^{-1}\right)$ are lower than average concentration in the earth's crust. The highest concentration sequence is as follow: $\mathrm{Cr}>$ $\mathrm{Zn}>\mathrm{Ni}>\mathrm{Cu}>\mathrm{Pb}>\mathrm{Co}>\mathrm{As}>\mathrm{Cd}>\mathrm{Hg}$.

\subsection{Bearing Comparison between Sampling Sites}

Highest concentrations of $\mathrm{Cr}\left(210 \mathrm{mg} \cdot \mathrm{kg}^{-1}\right)$ were found in Mbigala. It was followed by the one of Mboufa (200 $\left.\mathrm{mg} \cdot \mathrm{kg}^{-1}\right)$, Mari (180 $\left.\mathrm{mg} \cdot \mathrm{kg}^{-1}\right)$ and 


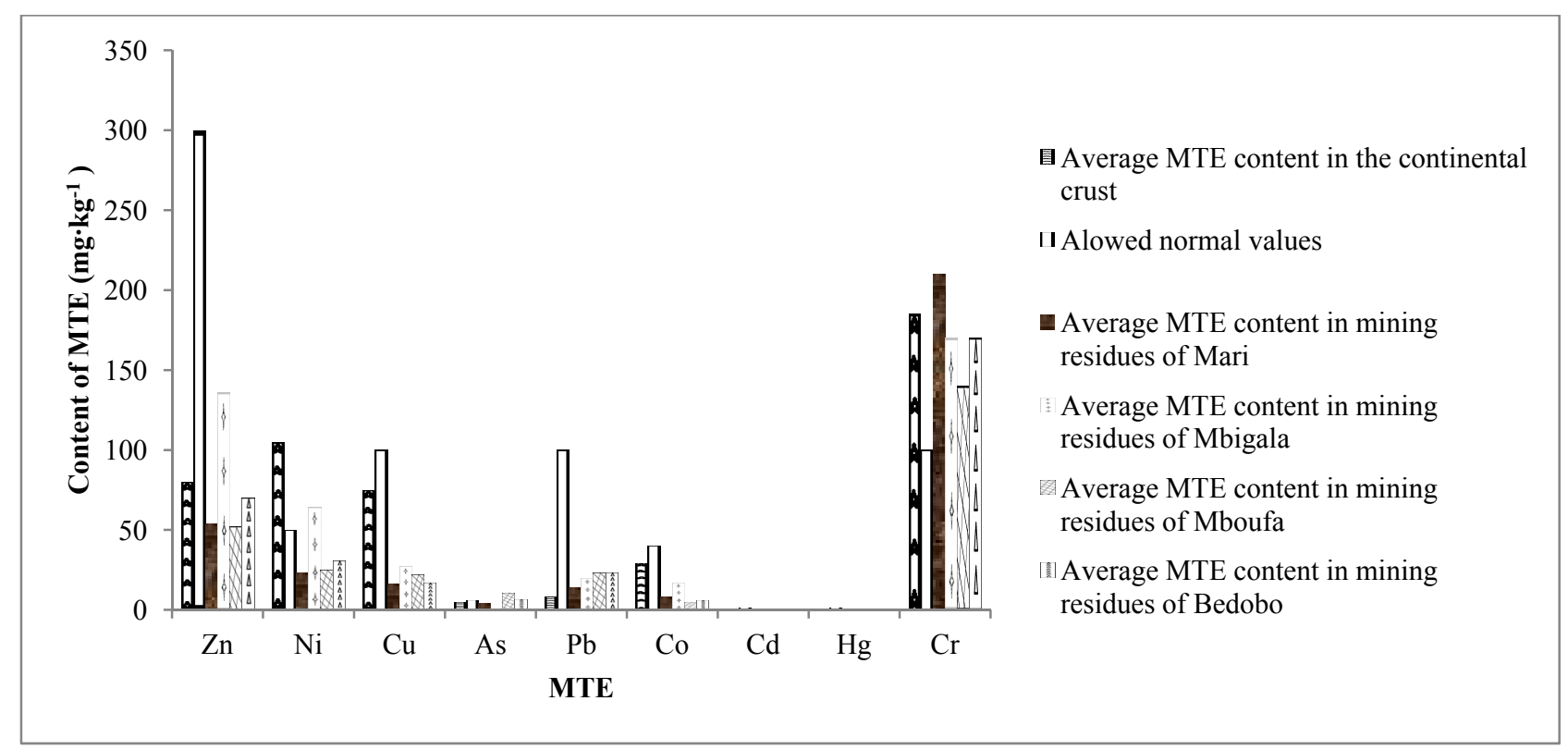

Fig. 7 Betare Oya concentration of MTE in mounds mining residues.

Bedobo $\left(150 \mathrm{mg} \cdot \mathrm{kg}^{-1}\right)$. It is then easy to draw a parallel between these concentrations with earth's crust content $\left(185 \mathrm{mg} \cdot \mathrm{kg}^{-1}\right)$, normal value in the soil (100 $\left.\mathrm{mg} \cdot \mathrm{kg}^{-1}\right)$ and soils of Addis Ababa (50-269 $\left.\mathrm{mg} \cdot \mathrm{kg}^{-1}\right)$ [18]. Zinc content changes significantly from Mbigala (136 $\left.\mathrm{mg} \cdot \mathrm{kg}^{-1}\right)$, Mboufa $\left(85 \mathrm{mg} \cdot \mathrm{kg}^{-1}\right)$, Bedobo $\left(70 \mathrm{mg} \cdot \mathrm{kg}^{-1}\right)$ to Mari $\left(11 \mathrm{mg} \cdot \mathrm{kg}^{-1}\right)$. Two sites over four have shown $\mathrm{Zn}$ concentrations exceeding the average in the earth crust $\left(80 \mathrm{mg} \cdot \mathrm{kg}^{-1}\right)$, while three of them are exceeding normal range values of Lagos (0.5-3.4 $\left.\mathrm{mg} \cdot \mathrm{kg}^{-1}\right)$ [19]. However, Betare Oya range concentration $\left(11.0-85.0 \mathrm{mg} \cdot \mathrm{kg}^{-1}\right)$ is lower than the one of most soils in Niamey (179.9-1703.0 $\left.\mathrm{mg} \cdot \mathrm{kg}^{-1}\right)$ [20]. Ni content ranges from 7.0-64.0 $\mathrm{mg} \cdot \mathrm{kg}^{-1}$. Mbigala (64 $\mathrm{mg} \cdot \mathrm{kg}^{-1}$ ) has the highest concentration, while Mari $\left(7 \mathrm{mg} \cdot \mathrm{kg}^{-1}\right)$ has the lowest. Betare Oya soils are similar to those of Ngaoundere lined between $6.2-47.4 \mathrm{mg} \cdot \mathrm{kg}^{-1}$ [21]. $\mathrm{Cu}$ values range from $7.0-30.0 \mathrm{mg} \cdot \mathrm{kg}^{-1}$. Bedobo $\left(30 \mathrm{mg} \cdot \mathrm{kg}^{-1}\right)$ has the highest concentration, while Mari $\left(7 \mathrm{mg} \cdot \mathrm{kg}^{-1}\right)$ has the lowest. Betare Oya soils concentrations in $\mathrm{Cu}$ are lower than the one of the earth's crust $\left(75 \mathrm{mg} \cdot \mathrm{kg}^{-1}\right)$, but higher than those of Lagos (0.1-2.9 $\left.\mathrm{mg} \cdot \mathrm{kg}^{-1}\right)$ [22]. $\mathrm{Pb}$ concentrations vary from $5.0-25.0 \mathrm{mg} \cdot \mathrm{kg}^{-1}$. Three concentrations: Bedobo (25 $\left.\mathrm{mg} \cdot \mathrm{kg}^{-1}\right)$, Mbigala (13 $\left.\mathrm{mg} \cdot \mathrm{kg}^{-1}\right)$, and Mboufa $\left(10 \mathrm{mg} \cdot \mathrm{kg}^{-1}\right)$ exceed the average in the earth crust $\left(8 \mathrm{mg} \cdot \mathrm{kg}^{-1}\right)$. Mari with $5 \mathrm{mg} \cdot \mathrm{kg}^{-1}$ has the lowest concentration, but it is higher than those of Lagos (0.5-3.4 $\left.\mathrm{mg} \cdot \mathrm{kg}^{-1}\right)$ and Niamey $\left(0.2-2.3 \mathrm{mg} \cdot \mathrm{kg}^{-1}\right)$. In Betare Oya, As contents range from 1.4-37.1 $\mathrm{mg} \cdot \mathrm{kg}^{-1}$. The average concentration in the earth's crust for this element is $5 \mathrm{mg} \cdot \mathrm{kg}^{-1}$, while the highest concentration at Bedobo, Mbigala, Mboufa and Mari are $37.1,18,10.6$ and $4.1 \mathrm{mg} \cdot \mathrm{kg}^{-1}$, respectively. These concentrations are higher than concentration range (1.36-13.70 $\left.\mathrm{mg} \cdot \mathrm{kg}^{-1}\right)$ in the soils of Niamey, and comparable to those of Moscow $\left(8-25 \mathrm{mg} \cdot \mathrm{kg}^{-1}\right)$ [23]. Co contents vary from $2.0-17.0 \mathrm{mg} \cdot \mathrm{kg}^{-1}$ at Betare Oya. The lowest level of Co was found at Mari $\left(2 \mathrm{mg} \cdot \mathrm{kg}^{-1}\right)$. In general, Co concentrations in the four sites are lower than normal value $\left(40 \mathrm{mg} \cdot \mathrm{kg}^{-1}\right)$ authorized by the WHO [15]. Hg levels range from 5.0-57.0 $\mu \mathrm{g} \cdot \mathrm{kg}^{-1}$. These concentrations are beneath the critical value (1 $\left.\mathrm{mg} \cdot \mathrm{kg}^{-1}\right)$, the limit value applied in Netherlands and Slovakia $\left(0.3 \mathrm{mg} \cdot \mathrm{kg}^{-1}\right)$, and the limit value applied in China (1.5 $\left.\mathrm{mg} \cdot \mathrm{kg}^{-1}\right)$ [24]. Cd concentrations rarely exceed $0.5 \mathrm{mg} \cdot \mathrm{kg}^{-1}$ at Betare Oya. But these levels are higher than the average in the earth crust $\left(0.1 \mathrm{mg} \cdot \mathrm{kg}^{-1}\right)$, and the referential value $\left(1.0 \mathrm{mg} \cdot \mathrm{kg}^{-1}\right)$ is given by the British agency for urban soils [25]. 


\section{Discussion}

The average levels of MTE in mounds mining residues show a clear increase compared to soils concentrations of Betare Oya. This is probably the result of mining proceeding related to the treatment and enrichment of gold ore due to usage of reagent substances (silver, platinum, etc.).

Mining residues used as backfield in wells and mining excavations are prone to weathering and transportation by meteoric water and wind. Indeed, erosion rate and moved material amount depends, on the one hand, on climate factors intensity (rain, wind, temperature...), and, on the other hand, on characteristics of residues (particle size, moisture ...), their location and the storage way (shape, position in the watershed...) [26]. Waste mounds mining residues, composed of silty-sandy particles $(72.50 \%)$ and high organic matter content $(36.48 \%)$, are in low physical stability, and are vulnerable to bad weather. They can be easily scattered and transported through rivers and landscapes. In long term, they are an impending source of pollution for nearby streams, groundwater and vicinity soils [27].

If high values of MTE recorded at Betare Oya are preferentially attributed to the geochemical background (natural) of the region, other emissions sources related to human activities (road traffic, landfills, agricultural activities and liquid effluents) may not be excluded. In fact, garbage, old packaging, car wrecks with tanks that contain fuel (oil, gasoline, and grease), tires, batteries, plastics, rubber, expired products founded in mining sites can also contribute to the increased concentrations of MTE in the environment [27].

The most visible manifestation of pollution is the degradation of the environmental milieu. Indeed, mining has induced considerable pressure on wood resources, contributing to landscape deforestation. The destruction of galleries forests is often accentuated by the search for gold nuggets deemed to be in hydromorphic alluvial soil under the roots of trees. All these actions lead to the weakening of the canopy and the gradual disappearance of protected species such as stilt roots that limit erosion in this environment (Fig. 2). Landscape due to this important perturbation is now made of alternating large mining residues piles and big gaping holes that gradually transform into artificial lake. Mineralized layers and backgrounds with poor organic material are then brought to surface. Ore extraction leaves open excavations without any restoration, leads to a significant degradation of soils, thus contributing to the reduction of arable land. Natural valleys have given way to impressive mounds of cuttings and gaping holes sometimes filled with stagnant water (Fig. 3). These artificial settings are real traps to farmers and cattle in search of pasture. They are the headquarters of disease multiplication and vectors (malaria, water-borne diseases).

During mining activities, the course of the main water flows exploited is modified. In fact, the riverbeds and major banks "flats" are full of mineralization. To allow recovery of this mineralization, companies carry out trenches along the shelf break where water is diverted. The entire water system is therefore changed in the area of operation. These changes caused environmental impacts that have been classified according to their destructive intensity (Table 2).

\section{Conclusions}

Betare Oya opencast mining and his immediate vicinity are liable to pollution. Soils and mounds mining residues were sampled in four sites for the determination of nine metallic trace elements $(\mathrm{Zn}, \mathrm{Ni}$, $\mathrm{Cr}, \mathrm{Cu}, \mathrm{As}, \mathrm{Pb}, \mathrm{Co}, \mathrm{Cd}$ and $\mathrm{Hg}$ ) concentrations by ICP-MS. Highest contents sequence of MTE in soils and mound mining residues is as follows: $\mathrm{Cr}>\mathrm{Zn}>$ $\mathrm{Ni}>\mathrm{Cu}>\mathrm{As}>\mathrm{Pb}>\mathrm{Co}>\mathrm{Cd}>\mathrm{Hg}$. Concentrations of $\mathrm{Pb}, \mathrm{Zn}, \mathrm{Cd}$, As and $\mathrm{Cr}$ are sometimes higheer than the average level in the continental crust and other normal values authorized by the WHO. Their harmful nature is a risk for environment, populations and animals. 
Table 2 Summary assessment of environmental threats due to mining in Betare Oya.

\begin{tabular}{llllll}
\hline \multirow{2}{*}{ Environmental elements impacted } & \multicolumn{5}{c}{ Modifications } \\
\cline { 2 - 6 } & Deforestation & $\begin{array}{l}\text { Landscape } \\
\text { alteration }\end{array}$ & $\begin{array}{l}\text { Water intake by } \\
\text { pumping }\end{array}$ & $\begin{array}{l}\text { Deviation of river } \\
\text { beds }\end{array}$ & Storage of cuttings \\
\hline Gallery forest & +++++ & +++++ & ++ & +++ & ++ \\
Aquatic fauna and flora & +++++ & +++++ & +++++ & +++++ & +++ \\
Soils & +++++ & +++++ & ++++ & ++++ & +++++ \\
Water system & + & +++++ & ++++ & +++++ & +++++ \\
Relief & + & +++++ & +++ & ++++ & ++++ \\
Quality of water & + & +++++ & +++++ & +++++ & +++++ \\
Agriculture & +++++ & +++++ & +++++ & +++++ & +++++ \\
Livestock & ++++ & ++++ & ++++ & +++ & +++++
\end{tabular}

Different levels of environmental destruction: + very low; + + low; +++ moderate; ++++ high; +++++ very high.

Results obtained in this work should enable awareness for a better environmental management to prevent water and soils pollution risks, and a better monitoring of mining activities in Cameroon.

\section{References}

[1] Laplaine, L. 1969. Index and Mineral Resources of Cameroon. Report of mining and geology department.

[2] Gazel, J. 1955. Explanatory Notice on Mining and Geological Recognition Sheet 1/500000 (Batouri-Ouest). Yaounde, Cameroon: Archives Service of Mining and Geology /Ministry of Water and Energy.

[3] Eno Belinga, S. M., and Vicat, J. P. 1999. Cameroon Thousand Centuries before Jesus Christ or Nature Great Secrets in the Wonderful History of Cameroonian Touristic Sites. Yaounde: Yaounde University Press.

[4] Ndjigui, P. D., Bilong, P., Nyeck, B., Eno Belinga, S. M., Vicat, J. P., and Gerard, M. 1999. Morphlogy, Mineralogy and Geochemistry of Two Lateritic Logs of Douala Coastal Plain (Cameroon). Cameroun: GEOCAM.

[5] Vairon, J., Edimo, A., Simeon, Y., and Valada, P. 1986. Memorandum of Understanding for Gold Mineralization Research in Eastern Province (Cameroun). Batouri Gold Mission, Second and Third Stages. Orleans: Geology and Mining Research Bureau-Direction of Mining Activities.

[6] Ntep Gweth, P., and Adeline, T. 2005. Environmental Study of the Lom Pangar Dam. Mining Study-Stage 4. Report of Isl-Oreade-Breche.

[7] CAMP (Cameroon Artisanal Mining Project). 2014. Control Mission Report of Societies Involves in Mechanism of Artisanal Mining in the Eastern Region of Cameroon. Report of Cameroon Artisanal Mining Project.
[8] Moulay Laârabi, E. H., Mohamed, E. H., Mohamed, F., Abdelhak, B., Laïla, E. F., and Nadia, S. 2005. Environmental Impact of a Diverted Mining Site: Zeïda Case (High Moulouya, Morocco). Report of the scientific institute.

[9] Bowen, H. J. M. 1979. Environmental Chemistry of the Elements. London: Academic Press.

[10] Bouabdli, A., Saidi, N., El Founti, L., and Leblanc, M. 2004. Aouli Mine Impact on Water and Sediments of Moulouya Wadi (Morocco). National report of social history.

[11] Da Silva, E. 2014. ““'Soil and Earth-Worm” Interaction and Dynamic of Mercury in French Guyana." Doctor thesis, University of Paris East, Paris.

[12] Tomgouani, K., Khalid, E. M., and Bouzid, K. 2007. "Evaluation of Metallic Pollution of Agricultural Land Irrigated with Waste Water of Settat Town (Morocco)." Sciences de la Vie 29: 89-92.

[13] Baize, D., and Paquereau, H. 1997. Total Content of Trace Elements in Agricultural Land of Seine-et-Marne. Vol. 4. Paris: Study and Soils Management.

[14] Godin, P. 1982. "Contamination Source and Stake." Presented at the Seminar on Trace Elements and Soils Pollution, Paris.

[15] Mench, M., and Baize, D. 2004. Soils and Crops Contamination by Trace Elements. Vol. 52. Paris: National Institute of Research.

[16] Ministry of Environment. 2001. Cobalt in Environment. Ontario: Ministry of Environment.

[17] Foucault, A. 1995. Geology Dictionary. Paris: Masson.

[18] Alemayehu, T. 2006. "Heavy Metallic Concentration in the Urban Environment of Addis Ababa-Ethiopia." Soil and Sediment Contamination 15: 591-602.

[19] Alexandre, M. J., and Pasquini, M. W. 2004. "Chemical Properties of Urban Waste Ash Produced by Open Burning on the Joss Plateau: Implication for Agriculture." Sciences of the Total Environment 319 (1-3): 225-40. 
[20] Tankari Dan-Badjao, A., Guero, Y., Dan Lamson, N., Tidjani, A. D., Ambouta, K. J. M., Feidt, C., Sterckeman, T., and Echevarria, G. 2013. Evaluation of Soils Contamination by Metallic Trace Elements in Niamey Urban and Peri-Urban Zone (Niger). Niamey: Bio-Resources Review.

[21] Adja, R., Feuze, W. M., Tchatueng, J. B., Sorho, S., Echeverria, G., and Ngassoum, M. B. 2008. "Long-Term Effect of Municipal Solid Waste Amendment on Soil Heavy Metallic Content of Site Used for Peri-urban Agriculture in Ngaoundere, Cameroon." African Journal of Science and Technology 2 (12): 412-21.

[22] Awofolu, O. R. 2005. “A Survey of Trace Metallic's in Vegetation, Soil and Lower Animal along Some Selected Major Roads in Metropolitan City of Lagos." Environmental Monitoring and Assessment 105: 431-47.

[23] Alexandrovskaya, E. I., and Alexandrovskiy, A. L. 2000. "History of the Cultural Layer in Moscow and
Accumulation of Urban Surface Soils, the Example of Pforzheim, Germany." Applied Geochemistry 21: 2064-81.

[24] Switzerland Confederation of Mercury in Soil. 2013. Mercury in Soil: Establishment of a Sanitation Value According to Osite and Doorway of Investigation According to Osol. Report on the Commission of the OFEV (Federal Office of Environment).

[25] Bureau of Research in Geology and Mining. 1999. French Mining Residues: Classification and Main Environmental Impacts. Paris: Technical and Mining Industry.

[26] Sighomnou, D. 2004. "Analysis and Redefinition of Climate Speed and Hydrology of Cameroon: Water Resources Evolution." Ph.D. thesis, University of Yaounde I.

[27] Kabata-Pendias, A., and Pendias, H. 2000. Trace Elements in Soils and Plants. Florida: CRC Press. 